\title{
LOSS OF VIGOR IN CONILON COFFEE SEEDLINGS DUE TO THE APPLICATION OF GRANULAR FUNGICIDE FOR SOIL
}

\author{
MARTINS, Lima Deleon ${ }^{1}$ \\ RODRIGUES, Wagner Nunes ${ }^{2}$ \\ TOMAZ, Marcelo Antonio ${ }^{3}$ \\ SOUZA, Antonio Fernando de Souza ${ }^{4}$ \\ JESUS JUNIOR, Waldir Cintra $d^{3}$ \\ DONATELLI JUNIOR, Érido José ${ }^{5}$
}

SUMMARY: Coffee leaf rust (Hemileia vastatrix) is the disease with the greater potential to do damage to coffee plantations. Diversified products are available for its control, for example, there are fungicides of granular from that are applied in the soil, such as cyproconazole+thiamethoxam. But there is a secondary effect associated with those products called 'tonic effect' which is characterized by the promotion of a high vigor in the plant, increasing the foliage and also the green tone of the leaves. However, this tonic effect can cause metabolic problems in the plant. The objective of this study was to evaluate the influence of the application of a granular fungicide applied in the soil (cyproconazole+thiamethoxam) in the vigor of seedlings of conilon coffee clones that compose the cultivar 'Vitória Incaper 8142', in greenhouse conditions. All the clones, grown in greenhouse, showed a reduction in their vigor when the application of the granular fungicide was done.

Keywords: Chemical control. Coffea canephora. Hemileia vastatrix.

\section{PERDA DE VIGOR EM MUDAS DE CAFÉ CONILON DEVIDO À APLICAÇÃO DE FUNGICIDA GRANULADO DE SOLO}

RESUMO: A ferrugem do cafeeiro (Hemileia vastatrix) é a doença com maior potencial de danos à lavoura cafeeira. Produtos diversificados estão disponíveis para o seu controle, por exemplo, temos fungicidas sistêmicos de fórmula granulada de aplicação via solo, como o ciproconazol+tiametoxam. Existe um fator secundário associado aos granulados de solo chamado de 'efeito tônico' que se caracteriza pela promoção de um alto vigor na planta, aumentando o enfolhamento e também o tom de verde das folhas. Todavia, este efeito tonificador pode provocar distúrbios metabólicos na planta. Objetivou-se com este trabalho, avaliar a influência da aplicação de fungicida granulado de solo (ciproconazol+tiametoxam) no vigor de mudas de clones de café conilon que compõem a cultivar 'Vitória Incaper 8142', em casa de vegetação. Todos os clones, cultivados em casa de vegetação, apresentaram redução de vigor vegetativo quando da aplicação do fungicida granulado de solo.

\footnotetext{
${ }^{1}$ M. Sc. Student, Centro de Ciências Agrárias, Universidade Federal do Espírito Santo (CCA/UFES), Alegre, ES, Brazil. E-mail: deleon_lima@hotmail.com (Author for correspondence)

${ }^{2}$ D. Sc. Student, Centro de Ciências Agrárias, Universidade Federal do Espírito Santo (CCA/UFES), Alegre, ES, Brazil. E-mail: wagnernunes86@hotmail.com

${ }^{3}$ D. Sc., Professor, Departamento de Produção Vegetal, Centro de Ciências Agrárias, Universidade Federal do Espírito Santo (CCA/UFES), Alto Universitário, s/nº Cx Postal 16, Bairro Guararema, CEP: 29500-000, Alegre, ES, Brazil.E-mail: tomaz@cca.ufes.br,wcintra@cca.ufes.br

${ }^{4}$ D. Sc., Professor, Instituto Federal de Educação, Ciência e Tecnologia do Espírito Santo (IFES), Santa TeresaES, E-mail: anfersouza@ yahoo.com.br

${ }^{5}$ Agronomy Student, Scientific Initiation, Centro de Ciências Agrárias da Universidade Federal do Espírito Santo (CCA/UFES). E-mail: eridojdj@ hotmail.com
} 
Palavras-chave: Controle químico. Coffea canephora. Hemileia vastatrix.

\section{INTRODUCTION}

The coffee leaf rust (Hemileia vastatrix) is the disease with the greatest potential to do damage to coffee plantations. The fungus causes lesions on leaves, which reduces the photosynthetic area, and also can cause defoliation, jeopardizing the productivity of coffee plantation for the next year (ZAMBOLIM et al., 2002).

The chemical control of the coffee leaf rust is widely studied in Brazil (RIBEIRO; ARAÚJO, 2000, MARTINS et al., 2009). The scientific research is based on the continuous seek for solutions to achieve a greatest efficiency in the control of this disease and also in the reduction of cost of the utilization of chemical products.

Diversified products and technologies of application are currently available, generating alternatives to its use in varied conditions of coffee plantations (MATIELLO et al., 2006). The granular formula of systemic fungicides applied on the soil represents one of those alternatives. The application of a granular fungicide on soil, associated or not with insecticide ingredients, represents an alternative to the management of leaf rust in coffee plantations that have adverse characteristics, as in crops located in excessively steep relief, or extensive plantations or even in crops with high density of plantation (SILVA-ACUNÃ et al., 1993).

A secondary factor associated with the granular fungicides of soil is the physiological effect that is generated in plants due its application. This influence is called 'tonic effect', and is characterized by the promotion of a high vigor in the plant, increasing the foliage and also the green tone of leaves (CARVALHO et al. 1997).

This tonic effect is desirable, because it can actively influence the leaves, promoting a greater resistance and reducing the possibility of infections caused by biotic agents, such as the coffee leaf rust. However, this effect can cause a tonic metabolic breakdown in the plant, due to various sources, such as the application of these products on young plants, nutritional imbalance or lack of soil moisture, which can cause a reduction in the life cycle of the crop (ZAMBOLIM et al., 2009).

In the literature, there are few works that illustrate the phytotoxicity of granular systemic fungicides in conilon coffee plants. Thus, the aim of this work was to evaluate the influence of the application of a granular fungicide applied in the soil (cyproconazole+thiamethoxam) in the vigor of seedlings of conilon coffee clones that compose the cultivar 'Vitória Incaper 8142', in greenhouse conditions. 


\section{METHODOLOGY}

The experiment was conducted under a controlled environment, in greenhouse conditions, in the experimental area of the Centro de Ciências Agrárias da Universidade Federal do Espírito Santo (CCA-UFES), in the city of Alegre, Espírito Santo state, on the period between the months of October 2009 to February 2010.

The seedlings of the 13 clones that compose the cultivar 'Incaper Vitória 8142' were grown in plastic pots with capacity for $10 \mathrm{dm}^{3}$. The soil, classified as clayey yellow oxisol, was collected at a depth of 20 to $40 \mathrm{~cm}$, discarding the first $20 \mathrm{~cm}$ of the soil profile in order to reduce the effect of the organic matter, that is more pronounced in the surface soil layers. The collected soil was chemically and physically analyzed (Table 1), dried on shade, harrowed and homogenized in a 2,00 $\mathrm{mm}$ mesh sieve.

Table 1. Physical and chemical properties of the soil used in the study.

\begin{tabular}{|c|c|}
\hline Soil properties & Values \\
\hline Coarse sand $\left(\mathrm{g} \mathrm{kg}^{-1}\right)^{[1]}$ & 410,0 \\
\hline Fine sand $\left(\mathrm{g} \mathrm{kg}^{-1}\right)^{[1]}$ & 73,0 \\
\hline Silt $\left(\mathrm{g} \mathrm{kg}^{-1}\right)^{[1]}$ & 91,0 \\
\hline Clay $\left(\mathrm{g} \mathrm{kg}^{-1}\right)^{[1]}$ & 426,0 \\
\hline Soil density $\left(\mathrm{kg} \mathrm{dm}^{-3}\right)^{[2]}$ & 1,2 \\
\hline $\mathrm{pH}^{[3]}$ & 5,9 \\
\hline $\mathrm{P}\left(\mathrm{mg} \mathrm{dm}^{-3}\right)^{[4]}$ & 3,0 \\
\hline $\mathrm{K}\left(\mathrm{mg} \mathrm{dm}^{-3}\right)^{[5]}$ & 125,0 \\
\hline $\mathrm{Ca}\left(\mathrm{cmol}_{\mathrm{c}} \mathrm{dm}^{-3}\right)^{[6]}$ & 2,1 \\
\hline $\operatorname{Mg}\left(\mathrm{cmol}_{\mathrm{c}} \mathrm{dm}^{-3}\right)^{[6]}$ & 0,9 \\
\hline $\mathrm{Al}\left(\mathrm{cmol}_{\mathrm{c}} \mathrm{dm}^{-3}\right)^{[7]}$ & 0,0 \\
\hline $\mathrm{H}+\mathrm{Al}\left(\mathrm{cmol}_{\mathrm{c}} \mathrm{dm}^{-3}\right)^{[8]}$ & 3,3 \\
\hline Organic matter $\left(\mathrm{g} \mathrm{kg}^{-1}\right)^{[9]}$ & 31,4 \\
\hline Sum of bases $\left(\mathrm{cmolc} \mathrm{dm}^{-3}\right)$ & 3,3 \\
\hline Potencial cation Exchange capacity $\left(\mathrm{cmolc} \mathrm{dm}^{-3}\right)$ & 6,6 \\
\hline Actual cation Exchange capacity $\left(\mathrm{cmolc} \mathrm{dm}^{-3}\right)$ & 3,3 \\
\hline Base saturation $(\%)$ & 50,2 \\
\hline Al saturation $(\%)$ & 0,0 \\
\hline
\end{tabular}

${ }^{T 1}$ Pipette method (slow agitation); ${ }^{[2]}$ Beaker method; ${ }^{[3]} \mathrm{pH}$ in water (ratio 1:2.5); ${ }^{[4]}$ Extracted by Mehlich-1 and determined by colorimetry; ${ }^{[5]}$ Extracted by Mehlich-1 and determined by flame photometry; ${ }^{[6]}$ Extracted with potassium chloride $1 \mathrm{~mol} \mathrm{~L}^{-1}$ and determined by titration; ${ }^{[7]}$ Extracted with potassium chloride $1 \mathrm{~mol} \mathrm{~L}^{-1}$ and determined with atomic absorption spectrophotometer; ${ }^{[8]}$ Extracted with calcium acetate $0,5 \mathrm{~mol} \mathrm{~L}^{-1}, \mathrm{pH}$ 7,0 and determined by titration; ${ }^{[9]}$ Extracted by oxidation, wet way, with potassium dichromate in sulfuric acid and determined by titration (EMBRAPA, 1997).

The experimental design was completely randomized, in factorial distribution $13 \times 2$, with four replications, being the factors: 13 clones that compose the cultivar 'Incaper Vitória 8142' (V1, V2, V3, V4, V5, V6, V7, V8, V9, V10, V11, V12 and V13) and 2 levels of the application of the granular fungicide 'thiamethoxam-cyproconazole' in the soil (treated and not treated). 
The 13 superior clones that compose the cultivar 'Incaper Vitória 8142' were obtained in the genetic improvement program of the conilon coffee conducted by the Instituto Capixaba de Pesquisa, Assistência Técnica e Extensão Rural (INCAPER), after the selection, evaluation, characterization and clustering of conilon coffee clones throughout years of research. Until the time of this experiment, this clonal cultivar is the most recent release by the INCAPER for cultivation in Espírito Santo state (FONSECA et al., 2004). The seedlings for this experiment were obtained from a registered and certificated nursery.

The application of the active ingredients cyproconazole+tiametoxan in the soil was made by using the commercial product (Verdadero ${ }^{\circledR} 600 \mathrm{WG}$ ) granulated dispersible in water (WG). The manufacturer's recommended dose is 1000 g.ha ${ }^{-1}$ of the commercial product diluted in 400 liters of water. To adapt the manufacturer's recommendation for the utilization in the limited space of the pots, the methodology proposed by Martins et al. (2011) was used.

The product, that has granulated nature, was subjected to a slight maceration to facilitate the dilution. Each dose was weighed in a precision balance and applied with a syringe, $10 \mathrm{~cm}$ away of the seedlings over the entire soil surface, 20 days after the transplanting, being the doses per pot composed by $0,0703 \mathrm{~g}$ of the commercial product diluted in $29 \mathrm{ml}$ of water.

The fertilization with macro and micronutrients were made in accordance with the recommendation for the controlled environment (NOVAIS et al., 1991). The phosphoric fertilization was performed in a single dose at the planting. The fertilizations with nitrogen, potassium and micronutrients was performed in four applications, in coverage, starting 30 days after planting, with an interval of 30 days between applications.

The irrigation was performed by keeping the soil moist, throughout all of the experimental period, at $60 \%$ of the total pore volume of the soil, obtained with the density of particles and density of soil, determined by the test tube method, according to Embrapa (1997). The cultural treatments were performed manually according to the need.

The period of residual effect of the product cyproconazole+thiamethoxam in the plant varies between 120 and 150 days (SOUZA et al., 2009), so after 150 days of cultivation each experimental unit was used to analyze the plant vigor. This parameter corresponds to the capacity of adaptation of the plants to different growing conditions. The evaluation was done using a scale from 1 to 10 , with a score 1 corresponding to plants with reduced vigor and severe symptom of impoverishment, and the score 10 associated with plants with high vegetative vigor, more foliage and good growth (CARVALHO et al., 1979).

The collected data were subjected to variance analysis using the statistical software 'SISVAR' (FERREIRA, 2008) and the means comparison, when necessary, was made using 
the Tukey or Scott-Knott test $(\mathrm{p} \leq 0,05)$.

\section{RESULTS AND DISCUSSION}

The variance analysis indicated the significance $(\mathrm{p} \leq 0,01)$ of interaction between the effect of the evaluated factors, so the unfolding of these factors levels should be performed. The coefficient of variation (CV) found in the experiment was $10,35 \%$.

The application of the granular fungicide caused reduction of the vegetative vigor of all conilon coffee clones evaluated (Figure 1). Paradella et al. (2006), analyzing arabica coffee seedlings in the presence of triazole fungicides, of systemic action and applied on soil, also found that the growth of the seedlings were affected by the hormonal action of the granular fungicide of soil. When administered to seedlings in the nursery, or young plants in the field, the tonic effect of granular fungicides may be depressive, causing phytotoxicity in the treated plants (PARADELLA et al., 2006).

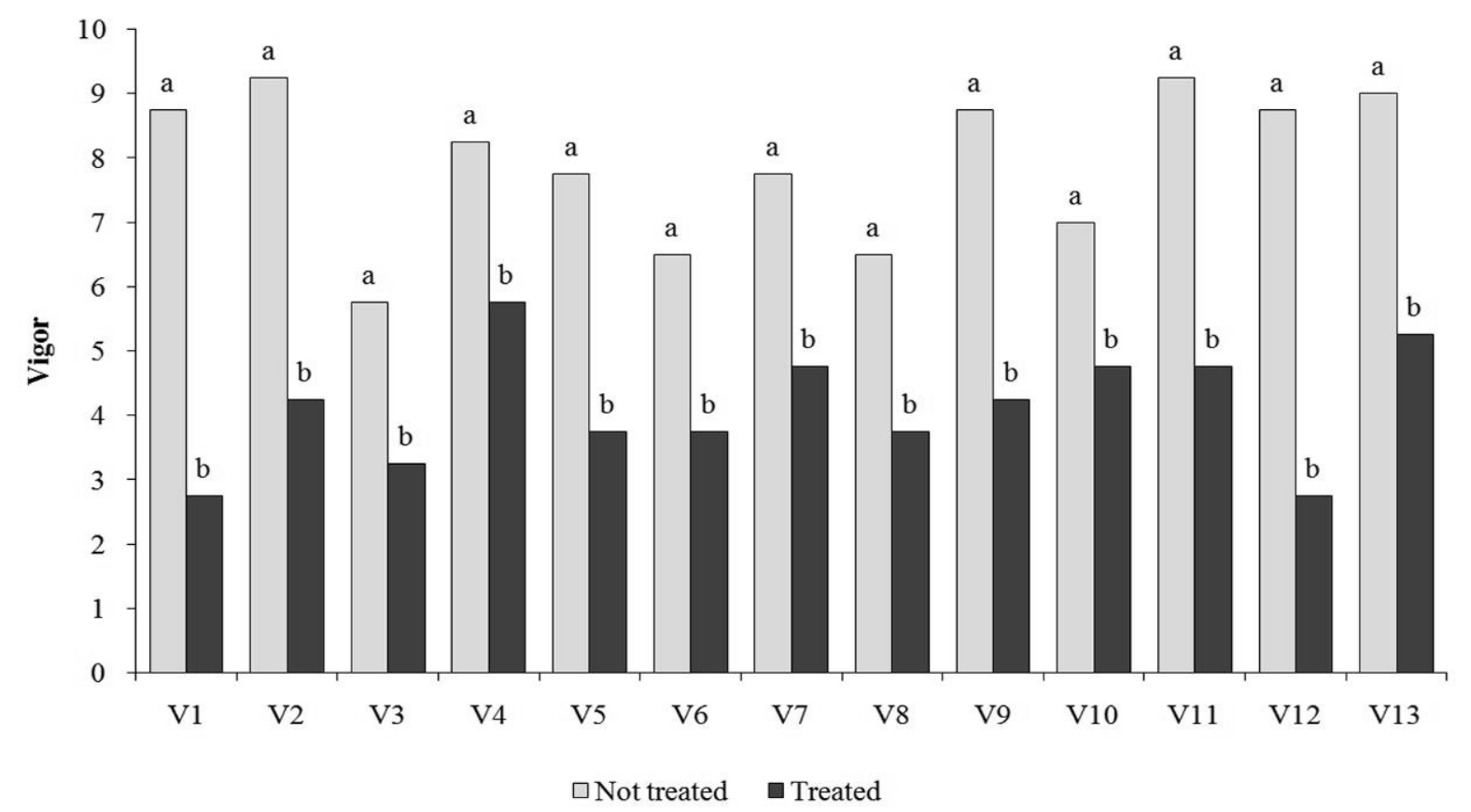

Figure 1. Mean values for vegetative vigor of conilon coffee clones treated and not treated with thiamethoxam+cyproconazole, Alegre-ES, 2010.

Means followed by the same letter, to each clone, do not differ from each other by the Tukey test at $5 \%$ of probability

The Figure 2 shows the comparison between the means of vigor for the 13 clones of the cultivar 'Incaper Vitória 8142' treated and not treated with thiamethoxam+cyproconazole. For the plants not treated with thiamethoxam+cyproconazole, the clones V1, V2, V9, V11, V12 and V13 formed the group with the highest means for vigor, while the clones V3, V6, V8 
and V10 formed the group of lower means.

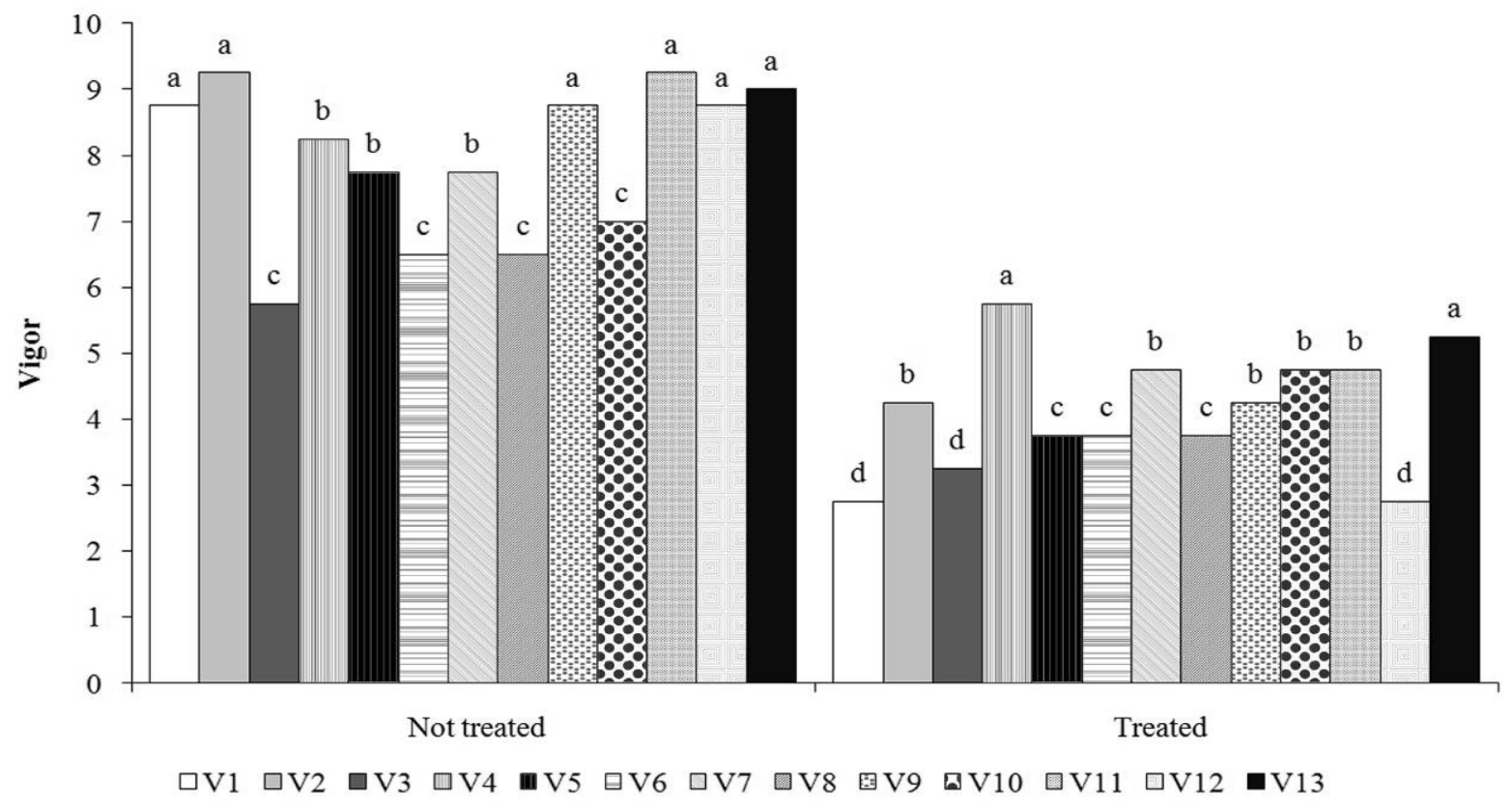

Figure 2. Mean values for vegetative vigor of the 13 clones of conilon coffee of the cultivar 'Vitória Incaper 8142', treated and not treated with thiamethoxam+cyproconazole, Alegre-ES, 2010.

Means followed by the same letter, to each level of granular fungicide application, do not differ from each other by the Scott-Knott test at $5 \%$ of probability

For the plants treated with the fungicide (cyproconazole+thiamethoxam), the clones V4 and V13 showed the highest means, followed by the clones V2, V7, V9, V10 and V11, the third group was composed of the clones V5, V6 and V8, and the group of lower means was formed by the clones V1, V3 and V12. A large depressing effect of the granular fungicide was noticed on the coffee clones, particularly shown on the clones V1 and V12, which presented means for vigor allocated in the group with the highest means when there was no application of fungicide, but were allocated on the group of lowest means for vigor when the product was applied (Figure 2).

The results are concordant with those obtained by Martins et al. (2011). These authors state that the application of thiamethoxam+cyproconazole may cause a reduction in the initial growth of seedlings of conilon coffee plants, in cultivation in controlled environment conditions. This reduction is due the phytotoxicity that the product may cause in young vegetal tissues, depending on the dosage.

Various symptoms, such as wrinkling, leaf spots, reduction of internodes, necrosis of leaves, leaf epinasty, tanning and stunting, were found in the tested plants (Figure 3). These results corroborate those found for Moraes (1974), showing that the application of systemic 
fungicide in the soil showed a satisfactory control of leaf rust, however, plants that received the application of the fungicide showed phytotoxic symptoms, mainly characterized by a reduced growth of the coffee plants.
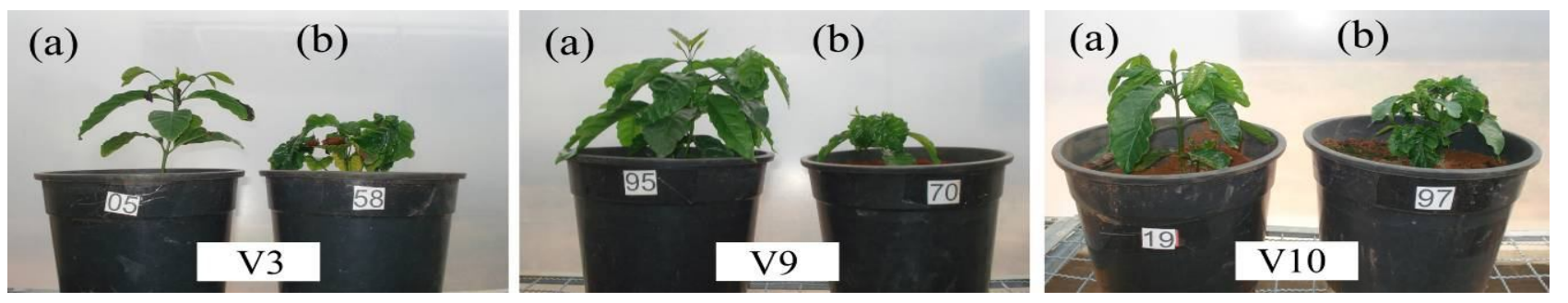

Figure 3. Conilon coffee plants from the clonal cultivar 'Vitória Incaper 8142 ' not treated (a) and treated (b) with cyproconazole+thiamethoxam, Alegre-ES, 2010.

According to Paradella et al. (2006), systemic fungicides of soil administered in nursery seedlings or young plants in the field, may have a depressive effect, causing phytotoxicity in the treated plants, due to the tonic effect.

\section{CONCLUSIONS}

Under the evaluated conditions, all the clones that compose the cultivar 'Incaper Vitória 8142' showed reduced vigor when treated with the granular fungicide of soil application: cyproconazole+thiamethoxam.

The clones V4 and V13 were less influenced by this vigor loss when treated with ciproconazol+tiametoxam.

\section{REFERENCES}

CARVALHO, A.; MÔNACO, L. C.; FAZUOLI, L. C. melhoramento do café. XL - Estudos de progênies e híbridos de café Catuaí. Bragantia, Campinas, v.38, n.22, p.202-216, 1979.

CARVALHO, G. R.et al. Efeito do triadimenol e benzilaminopurina no desenvolvimento de brotos in vitro do cafeeiro cv. catuaí. Revista Unimar, v.19, n.3, p.767-775, 1997.

EMBRAPA - Empresa Brasileira de Pesquisa Agropecuária. Manual de métodos de análises de solo. 2.ed. Rio de Janeiro: Ministério da Agricultura e do Abastecimento, 1997. 212p.

FERREIRA, D. F. SISVAR: um programa para análises e ensino de estatística. Revista Symposium, v. 6, p. 36-41, 2008.

FONSECA, A. F. A.; FERRÃO, M. A. G.; FERRÃO, R. G.; VERDIN FILHO, A. C.; VOLPI, P. S.; ZUCATELI, F. 'Conilon Vitória - Incaper 8142': improved Coffea canephora var. kouillou clone cultivar for the state of Espírito Santo. Crop Breeding and Applied Biotechnology, v.4, n.4, p.503-505, 2004. 
MARTINS, A. N.; SILVEIRA, A. P.; FURTADO, E. L. Avaliação do cloreto de benzalcônio no controle da ferrugem (Hemileia vastatrix Berk. ; Br.) do cafeeiro (Coffea arabica L.).

Summa phytopathologica, v.35, n.2, p.143-145, 2009.

MARTINS, L. D.et al. Influência da aplicação de ciproconazol+tiametoxam no crescimento de mudas de Coffea canephora Pierre ex A.Froehner. Revista de Ciências Agrárias, v.34, n. 1, p. 220-228, 2011.

MATIELlO, J. B.; GARCIA, A. W. R.; ALMEIDA, S. R. A. Adubos, corretivos e defensivos para lavoura cafeeira: indicações de uso. Varginha: Bom Pastor, 2006, 89p.

NOVAIS, R. F.; NEVES, J. C. L.; BARROS, N. F. Ensaio em ambiente controlado. In: OLIVEIRA, A. J.et al. Métodos de pesquisa em fertilidade do solo. Brasília: EMBRAPASAE, 1991. p.189-254.

PARADELA, A. L.et al. Avaliação do índice de fitotoxidez de triazóis em mudas de café e eficiência dos triazóis aplicados via foliar no controle da ferrugem (Hemileia vastatrix) do cafeeiro (Coffea arabica). Fitopatologia Brasileira, v.32, n.2, 2006.

MORAES, F. R. P. de. Absorção de fungicidas sistêmicos por via foliar e radicular no controle da ferrugem do cafeeiro (Hemileia vastatrix. Berk e Br). In: CONGRESSO BRASILEIRO SOBRE PESQUISAS CAFEEIRAS, 2., 1974. Poços de Caldas. Anais... Poços de Caldas, 1974. p.146-147.

RIBEIRO, A. A.; ARAÚJO, C. H. G. Controle da ferrugem e cercosporiose em cafeeiros com azoxistrobin e combinações com hexaconazole. In: CONGRESSO BRASILEIRO DE PESQUISAS CAFEEIRAS, 26., 2000. Marília. Anais... Marília, 2000. p.41-43.

SILVA-ACUNÃ, R.; ZAMBOLIM, L.; GONZALEZMOLINA, E. de C. Controle da ferrugem do cafeeiro com triadimenol via solo, na Venezuela. Fitopatologia Brasileira, v.18, n.1, p.70-75, 1993.

SOUZA, A. F. DE et al. Manejo fitossanitário da ferrugem e do bicho-mineiro dentro dos princípios da produção integrada do café. In: ZAMBOLIM L (Ed). Tecnologias para a produção do café conilon. Viçosa: Universidade Federal de Viçosa, 2009. p. 47-64.

ZAMBOLIM, L.et al. Epidemiologia e controle integrado da ferrugem do cafeeiro. In: ZAMBOLIM L (Ed). O Estado da arte de tecnologias na produção de café. Viçosa: UFV, 2002. p.369-450.

ZAMBOLIM, L.et al. Manejo integrado das doenças do conilon (Coffea canephora). In: Zambolim, L. (Ed) Tecnologias para a produção do café conilon. Viçosa: Universidade Federal de Viçosa, 2009. p. 01-46. 